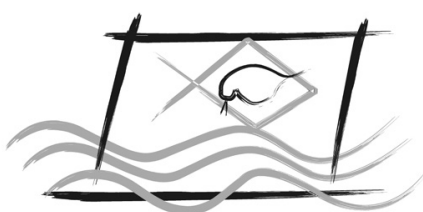

ECOTOX - BRASIL

\title{
The lack of information hides the impact of human activities in estuarine fish from Southern of Brazil
}

\author{
Torres, M.C. ${ }^{1 ;}$, Valdez Domingos, F.X. ${ }^{2}$; Rabitto, I.S. ${ }^{1}$; Randi, M.A.F. ${ }^{1}$ \& Oliveira Ribeiro, C.A. ${ }^{*}$ \\ ${ }^{1}$ Departamento de Biologia Celular, Universidade Federal do Paraná. C.P. 19031, CEP: 81.531-980, Curitiba-PR, Brasil \\ ${ }^{2}$ Laboratório Temático de Microscopia Óptica e Eletrônica, Instituto Nacional de \\ Pesquisas da Amazônia (INPA). CP. nº 2223, CEP 69067-375, \\ Manaus-AM, Brazil.
}

(Received June 26, 2015; Accept June 16, 2016)

\begin{abstract}
Brazilian coast are sites of significant chemical discharge impacting the estuaries, natural "nursery" of aquatic organisms. In order to investigate the human impact in Lagoa dos Patos - South of Brazil - gills and liver of croakers Micropogonias furnieri were used as morphological biomarkers . Forty individuals from reference and polluted sites were caught in winter and summer of 2003. The individuals were measured, weighted and liver and gills samples were processed for light and transmission and scanning electron microscopy. Individuals from the polluted area (winter) showed strong morphological evidences of chemical exposure. The observed ultrastructure lesions and alterations confirmed the worst conditions of individuals from polluted site mainly in winter. The sediment remobilization due to rainfall may be the cause of chemical bioavailability. Further chemical studies are necessary in Lagoa dos Patos as the risk of exposure to biota and human populations was demonstrated.
\end{abstract}

Keywords: Biomarkers, estuarine pollution, gills, histopathology, liver, Micropogonias furnieri.

\section{INTRODUCTION}

Estuaries and other coastal environments represent an important habitat for the initial stages of the life cycle of many marine organisms (Martins et al., 2007). The chemical discharge due to human activities such as industrial, agricultural and urban waste affect the health of aquatic organisms leading to mass mortality with serious ecological disturbs (Gusso-Choueri et al,. 2016). The Lagoa dos Patos estuary constitute important nursery grounds for many commercially relevant fish and shrimp species because they offer abundance of food (zooplankton) and protection from predators (Pearcy \& Myers, 1974). Thus this estuary is the most important nursery ground for commercially relevant species of fish and crustaceans in the South of Brazil, maintaining fisheries that sustain 3,500 families throughout the Rio Grande do Sul State coastline. Over $50 \%$ of the total fisheries production in the region is supported by sciaenid species, being the white croakers Micropogonias furnieri one of the most abundant and important species for local fisheries (Haimovic et al., 2006). According to Niencheski et al. (2001) M. furnieri exhibit mercury levels above the expected natural values in the same polluted area investigated in the current study. More recently Barbosa et al. (2012) described the presence of toxic metals (zinc, cupper, lead and zinc) in all port region. According to the same authors no variations of these metals on surface waters was found, including no seasonal variations. Medeiros et al. (2005) described values about $37.7 \mathrm{ng} / \mathrm{g}$ of PHAs in the same studied region and Luz et al. (2010) found $4.7 \mathrm{ng} / \mathrm{g}$ in a more distant region (northern of Lagoon). More recently Sanches Filho et al. (2012) described high levels of total PAHs (92.8 $\left.\mathrm{ng} \mathrm{g}^{-1}\right)$ in a region near to the studied area (Pelotas City).

Due to the bioavailability of pollutants to resident biota, the use of biomarkers may measure its effects and discuss the risk of exposure to both biota and human populations. Our more recent studies showed successfully that the use of fish as bioindicators using histopathology as biomarker 
in biomonitoring programs are crucial to evaluate the risks of exposure to pollutants in aquatic ecosystems (Brito et al., 2012; Rabitto et al., 2011; Bussolaro et al., 2012; Osório et al., 2014; Miranda et al., 2016). The white croakers M. furnieri is a demersal and carnivorous fish feeds on bottom fauna, mainly macro and microcrustacea, polychaeta, mollusca and smalls fishes (Kehrig et al., 1998). Due to the trophic position and importance for human diet, and, although it undergoes seasonal migration, Marcovecchio et al. (2004) and Amado et al. (2006) recommended the use of M. furnieri species as a sentinel in programs to investigate environmental health.

In the last years, the evaluation of the causal effects between contaminant exposure and fish health as biomarker in aquatic organisms has been strongly evident (Oliveira Ribeiro et al., 2005; Osorio et al., 2014; Rabitto et al., 2011, Miranda et al., 2016) providing useful information of historical exposure to sub-lethal toxicity (Cooley et al ., 2001; Stentiford et al., 2003). Somatic indexes are used as a biomarker of growth inhibition and histopathology findings identify target organs due to chemical exposure describing and evaluating the type and intensity of physiological disturbs. Together these data are strictly related with the intensity of pollution (Bussolaro et al., 2012; Osório et al., 2014; Gusso-Choueri et al., 2016). According to Rabitto et al. (2011), gills and liver are important ways of xenobiotics uptake in fish. Additionally, gill damages may lead to a decrease on fish health (Bussolaro et al., 2012) and liver damages has been widely recognized in environment studies (Oliveira Ribeiro et al., 2005; Osorio et al., 2014; Miranda et al., 2016).

According to the final report of the "Millenium Institute Program" from the Brazilian Ministry of Science and Technology, in Brazil, the absence of studies concerning coastal toxicology, represent a large limitation to establish a critical classification of impacted areas mainly due to human activities. Thus, any additional data are important and necessary to increase the knowledge in large-scale as base to conduct managements in the environmental politics to Brazilian coast.

\section{MATERIALS AND METHODS}

\section{Field Procedures}

The environmental parameters as temperature, salinity and dissolved oxygen (DO) were measured in both studied sites and seasons using a handheld multiparameter meter.

A sampling of ten adults specimens (per site) of Micropogonias furnieri were performed in August 2003 (winter) and February 2004 (summer) in two sites of the Patos Lagoon estuary (South of Brazil). One site is located closed to the "Marinheiros Island" in a region called "Arraial Inlet" $\left(32^{\circ} 02^{\prime} \mathrm{S}-52^{\circ} 12^{\prime} \mathrm{W}\right)$, which was considered the non-polluted or less polluted site (Site 1). The second studied area (Site $2)$ is located at the "Mangueira Inlet" $\left(32^{\circ} 05^{\prime} \mathrm{S}-52^{\circ} 07^{\prime} \mathrm{W}\right)$, which was previously characterized as a polluted one (Fig. 1). Fish collection was performed for $15 \mathrm{~min}$ using a trawl-net. Fish between 10 and $20 \mathrm{~cm}$ length were anaesthetized with benzocaine $(50 \mathrm{ppt})$ and total weight $(\mathrm{g})(\mathrm{TW})$, length $(\mathrm{cm})$ (TL) and liver weight (g) (LW) were taken. The second right brachial arch, and liver sample were preserved for light and transmission electron microscopy while the second left brachial arch was sampled for scanning electron microscopy analysis.

\section{Light and electron microscopy procedures}

Liver and gills samples were preserved in ALFAC (70\% ethanol, $4 \%$ formaldehyde, $5 \%$ glacial acetic acid) fixative solution for histopathological analysis (16 h), dehydrated in a graded series of ethanol baths and embedded in Paraplast Plus resin $\left(\right.$ Sigma $\left.^{\circledR}\right)$ after xylene clearance. The sliced sections $(5 \mu \mathrm{m})$ were stained in haematoxilin/eosin and observed in a Zeiss Axiophot photomicroscope. To evaluate the alterations
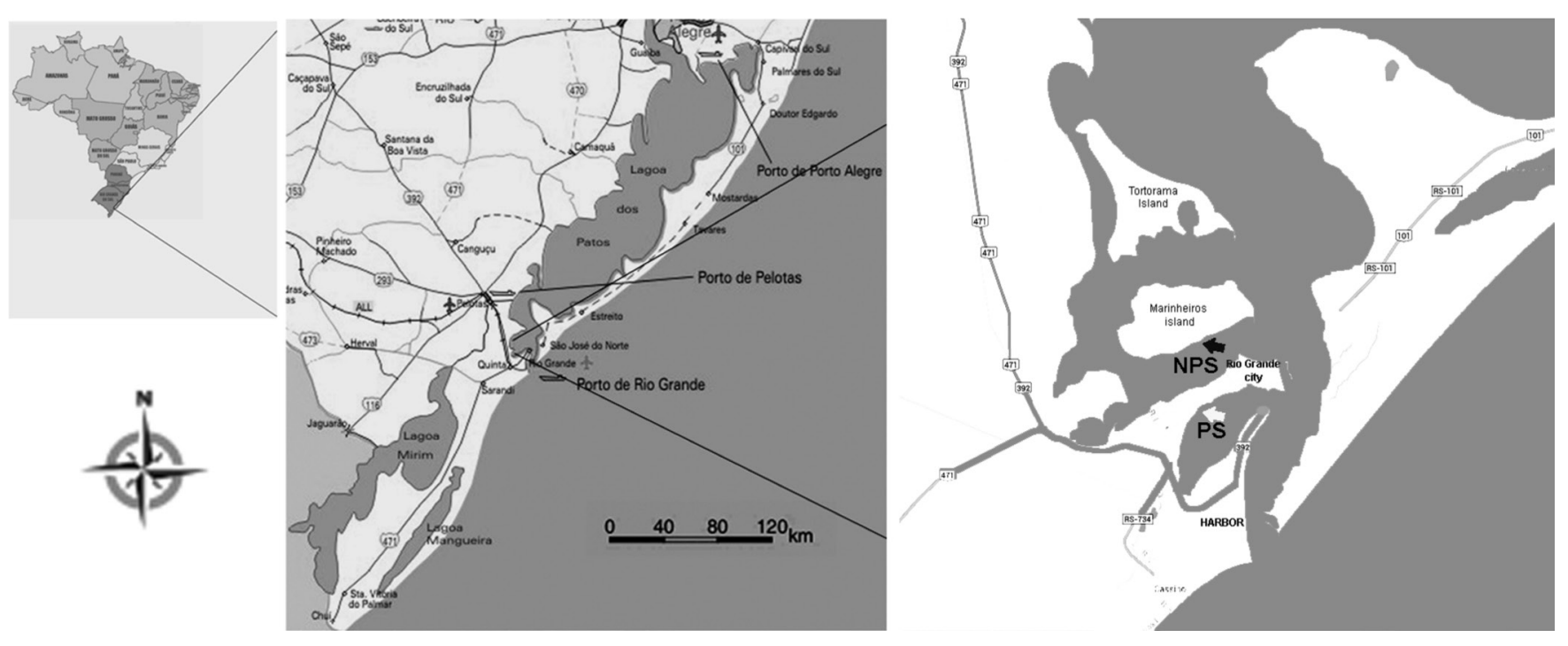

Figure 1. Map of the studied area. The black and white arrows indicate respectively the reference "Arraial Inlet" (NPS) $\left(32^{\circ} 02^{\prime} \mathrm{S}-52^{\circ} 12^{\prime} \mathrm{W}\right)$ considered as non polluted site and "Mangueira Inlet" (PS) $\left(32^{\circ} 05^{\prime} \mathrm{S}-52^{\circ} 07^{\prime} \mathrm{W}\right)$ as polluted site. 
and damages the occurrence of lesions was considered per individual as a percentage of incidence. For ultrastructure investigations, small liver samples $\left(2 \mathrm{~mm}^{3}\right)$ were preserved in $2 \%$ glutaraldehyde, $2 \%$ paraformaldehyde, $5 \mathrm{mM} \mathrm{CaCl}_{2}, 20 \mathrm{mM}$ $\mathrm{NaCl}$ dissolved in $0.1 \mathrm{M}$ cacodylate buffer $(\mathrm{pH} 7.2$ - 7.4) fixative solution at room temperature for $2 \mathrm{~h}$. The samples were post fixed in $1 \%$ osmium tetroxide in $0.1 \mathrm{M}$ cacodylate buffer solution (pH 7.2 - 7.4) for $1 \mathrm{~h}$, dehydrated in a graded series of ethanol $\left(\right.$ Merck $\left.^{\circledR}\right)$, propylene oxide (Electron Microscopy Science ${ }^{\circledR}$ ) and embedded in PoliEmbed 812 DER736 resin (Polysciences ${ }^{\circledR}$ ). The ultra-thin sections were contrasted by uranil acetate $(5 \%)$ for 20 minutes and lead citrate (Reynolds) for five minutes, and observed in a JEOL TEM 1200 EXII. For scanning electron microscopy the gills were preserved in glutaraldehyde (3\%) in cacodilate buffer $0.1 \mathrm{M}(\mathrm{pH} 7.2)$ fixative solution, dehydrated in ethanol and accomplished later on the critical point (liquid $\mathrm{CO}_{2}$ ), covered with gold and observed in a Jeol Scanning Electronic Microscopic. The analysis were performed in the Center of Electron Microscopy at Federal University of Parana. The ultrastructure evaluation was performed as a qualitative analysis only as the number of individuals and studied area in this kind of methods are very limited.

\section{Somatic Biomarkers}

Hepatosomatic index (HSI) reveals the proportion between liver (LW) and whole body (TW) weight, and was calculated by the following formula: HSI=LW/TW.100 (Milton et al., 1994). The condition factor $(\mathrm{K})$ can be used to compare populations exposed to different environmental conditions (Braga, 1986) indicating fish health status according to the environmental conditions. The following formula was used to calculate $\mathrm{K}$ values: $\mathrm{K}=\mathrm{TW} / \mathrm{TL}^{\mathrm{b}}$ (Vientini \& Araujo, 2002) where $\mathrm{TW}=\mathrm{Total}$ weight and $\mathrm{TL}=$ Total length while $b$ means the slope of the regression line in logarithmic form between independent variable data (size) and variable dependent data (weight). According to Hile (1936) the difference of exponent $b$ from 3.0 indicates the direction and "rate of change of form or condition". The exponent $b<3.0$ indicates a decrease in condition or elongation in form with increase in length, whereas $b>3.0$ indicates an increase in condition or in height or width with increase in length. According to the same author the exponent $b$ normally lies between 2.5 and 4.0 (Hile 1936, Martin, 1949) but an ideal fish condition in general maintains the same shape $(b=3.0)$.

\section{Histopathological analyses}

Liver slices areas were measured using a reticule ocular. Areas of necrosis, leukocytes, infiltration, hemorrhage, melanomacrophage centers (MMC) and melanomacrophages (MM) were counted and then divided by the total area of the slice, thus the results are expressed as alterations $/ \mathrm{mm}^{2}$.

\section{Statistical Procedures}

Data were verified for normality and homogeneity of variance or log-transformed to fit normal distribution. Then two- way anova test was performed. Data are expressed as means \pm standard deviation and significance level was set as $\mathrm{p}<0.05$.

\section{RESULTS}

\section{Environmental parameters}

The values of environmental parameters are summarized in the Table 1. As expected the temperature decrease in the winter and increased in the summer in both studied sites. In the winter the ocean current interfere decreasing the temperature in the polluted site closer to the open ocean. No variation of temperature were found between the studied sites in the summer. The results of salinity showed that the seasonality interfere increasing substantially the values at summer. When compared the studied sites at the same season, the salinity showed high variation in the winter increasing in the polluted site, differently that observed in the summer where the salinity values were lower in the polluted site. The dissolved oxygen showed a very low variation in reference site between winter and summer seasons, differently than observed to the polluted site where the dissolved oxygen in water was higher in winter. If compared the different seasons between the different sites, was observed that the polluted site presented higher dissolved oxygen in water and in the summer the opposite it is observed, the polluted site presented lower levels.

\section{Somatic Index Biomarkers and Biometry Data}

Somatic indexes were used as biomarkers (hepatossomatic index - HSI and condition factor - K) to evaluate the survival condition and growth alteration, using biometry data such as total length (TL) and weight (TW) and liver weight (LW). These data are summarized in Table 2. HSI was higher in individuals from the polluted site and no difference was observed between seasons, while $\mathrm{K}$ was higher in individuals captured during the winter from both sites. Individuals from reference site presented higher values of TL and TW during winter. LW was significantly higher during winter, but no difference was found between sites.

\section{Morphological Aspects}

A typical histological pattern of healthy gills is represented by secondary lamellae regularly lined up along both sides of

Table 1. Environmental parameters registered in winter 2003 and summer 2004 at the studied sites (Site $1=$ Reference; Site $2=$ Polluted) at Patos Lagoon estuary (Southern Brazil). Values are expressed as means \pm standard error.

\begin{tabular}{lccccc}
\hline & & Winter & \multicolumn{3}{c}{ Summer } \\
\hline Environmental Parameter & reference & polluted & reference & polluted & $n$ \\
\hline Temperature & $13 \pm 0$ & $9.5 \pm 0.3$ & $24.3 \pm 0.3$ & $24.3 \pm 0.5$ & 4 \\
Salinity & $0.2 \pm 0.1$ & $1.8 \pm 0.2$ & $11.4 \pm 3.8$ & $6.2 \pm 1.7$ & 4 \\
DO & $9.2 \pm 0.2$ & $10.1 \pm 0.3$ & $8.5 \pm 0.1$ & $7.6 \pm 0.4$ & 4 \\
\hline
\end{tabular}

$\mathrm{DO}=$ dissolved oxygen

$\mathrm{n}=$ number of measurements 
Table 2. Comparative somatic indexes of Micropogonias furnieri from both studied sites in winter (2003) and summer (2004) seasons (means \pm standard deviation and two-way anova test). TL: total length; TW: total weigh; LW: liver weigh; HSI: hepatosomatic index; K: condition factor (ten individuals per site)

\begin{tabular}{lcccc}
\hline & \multicolumn{2}{c}{ Winter } & \multicolumn{2}{c}{ Summer } \\
\hline Biometry Data & reference & polluted & reference & polluted \\
\hline TL & $\mathbf{1 4 . 8 3} \pm \mathbf{2 . 3 1}$ & $\mathbf{1 3 . 2 6} \pm \mathbf{1 . 6 1} *$ & $12.30 \pm 2.58$ & $9.45 \pm 2.49^{*}$ \\
TW & $\mathbf{3 3 . 0 2} \pm \mathbf{1 8 . 0 0}$ & $\mathbf{2 2 . 4 7 \pm \mathbf { 9 . 3 } 7 ^ { * }}$ & $20.64 \pm 11.79$ & $5.65 \pm 1.28^{*}$ \\
LW & $\mathbf{0 . 4 8} \pm \mathbf{0 . 2 5}$ & $\mathbf{0 . 4 1} \pm \mathbf{0 . 2 3}$ & $0.23 \pm 0.19$ & $0.10 \pm 0.10$ \\
\hline Somatic Index & & & & \\
\hline HSI & $0.86 \pm 0.72$ & $1.81 \pm 0.49^{*}$ & $1.20 \pm 0.72$ & $1.59 \pm 1.23^{*}$ \\
K & $\mathbf{0 . 0 0 9 6 \pm 0 . 0 0 0 7}$ & $\mathbf{0 . 0 0 7 3} \pm \mathbf{0 . 0 0 0 4}$ & $0.0055 \pm 0.0039$ & $0.0048 \pm 0.0033$
\end{tabular}

Bold means differences between seasons and $\left(^{*}\right)$ differences between sites.

the primary lamellae. Mucous and chloride cells are found sparsely scattered primarily at the base of the secondary lamellae whose epithelium is supported by contractile pilaster cells and separated by capillary channels (Fig. 2a, 3a and 3b). The occasional occurrence of parasites, secondary lamellae fusion, primary lamellae damages and hyperplasia were found in individuals from both studied sites (Fig. 2b-f and $3 \mathrm{c}-\mathrm{g}$ ). The epithelium cells edema observed in histological slices were confirmed by transmission electron microscopy (Fig. 3f-g), changing the lamellae structure. The pilaster cells vacuolization (Fig. $3 \mathrm{~g}$ ) may be related to the fusion of capillaries decreasing the blood cells influx and allowing to the occurrence of aneurisms.

Normal appearance of the liver is shown in Figure 4a, with hepathocytes arranged in cords, in general two cells thick between two sinusoids, presenting rounded nuclei with evident nucleoli and low chromatin density. A quite high diversity of damages, lesions and alterations in liver were observed. The occurrence of necrosis, leucocytes infiltration in hepatic parenchyma, hemorrhage, melanomacrophage centers (MMCs), basophilic and acidophilic foci and the frequent incidence of cellular megalopathy were described (Fig. 4). The occurrence of the most frequent histopathological findings is resumed in the Table 3. Most of the alterations were occasionally observed, but the presence of MMCs was significantly higher in individuals from the reference site comparatively with the polluted area. An increase in the incidence of necrosis and hemorrhage were observed during summer at both sites. Steatosis was also found in the liver of Micropogonias furnieri (Fig. 5d). Basophilic and acidophilic foci considered as neoplasic events were observed in two individuals from reference site sampled in winter. The disarrange of Disse's space and endoplasmic reticulum or even the proliferation of rough endoplasmic reticulum (respectively Fig. 5a, insert $5 \mathrm{~b}$ and insert $5 \mathrm{~d}$ ) were found in individuals from both sites. Other more serious lesions also appeared in individuals from these sites as the occurrence of atypical vesicles or cell death as necrosis (Fig. $5 \mathrm{~b}$ and $5 \mathrm{c}$ ).

Comparatively, individuals from both sites presented necrosis, atypical vesicles distributed in the cytosol, and

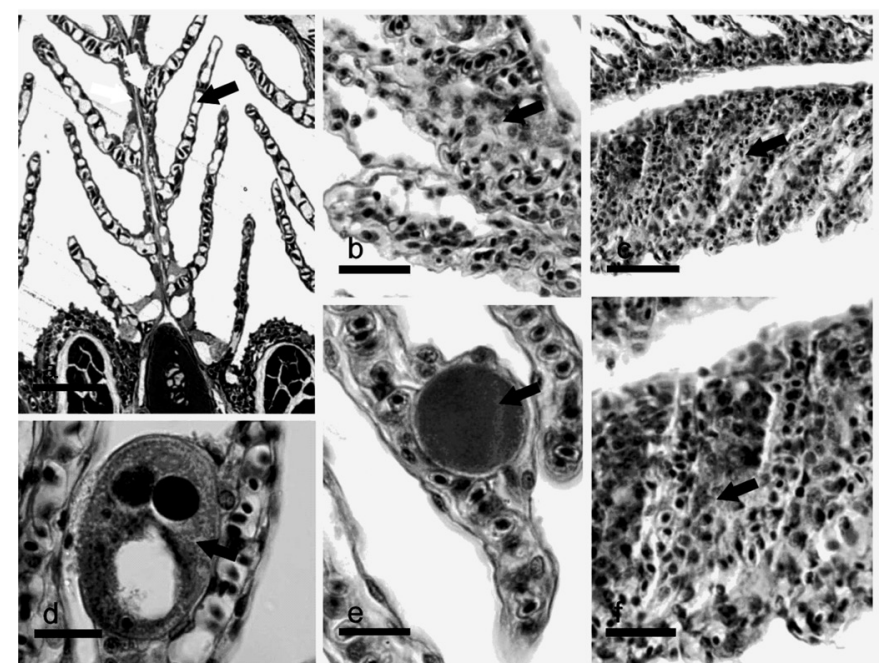

Figure 2. Gills histopathology analysis of Micropogonias furnieri. (a) Section with normal aspect of gills showing the primary (white arrow) and secondary lamellae (black arrow); (b) hyperplasia in the base of the secondary lamellae (arrow); (c) and (f) secondary lamellae fusion (arrows); (d) and (e) parasites. Bars (a) and (c): $5 \mu \mathrm{m}$; (b) and (f): $10 \mu \mathrm{m}$; (d) and (e): $5 \mu \mathrm{m}$.
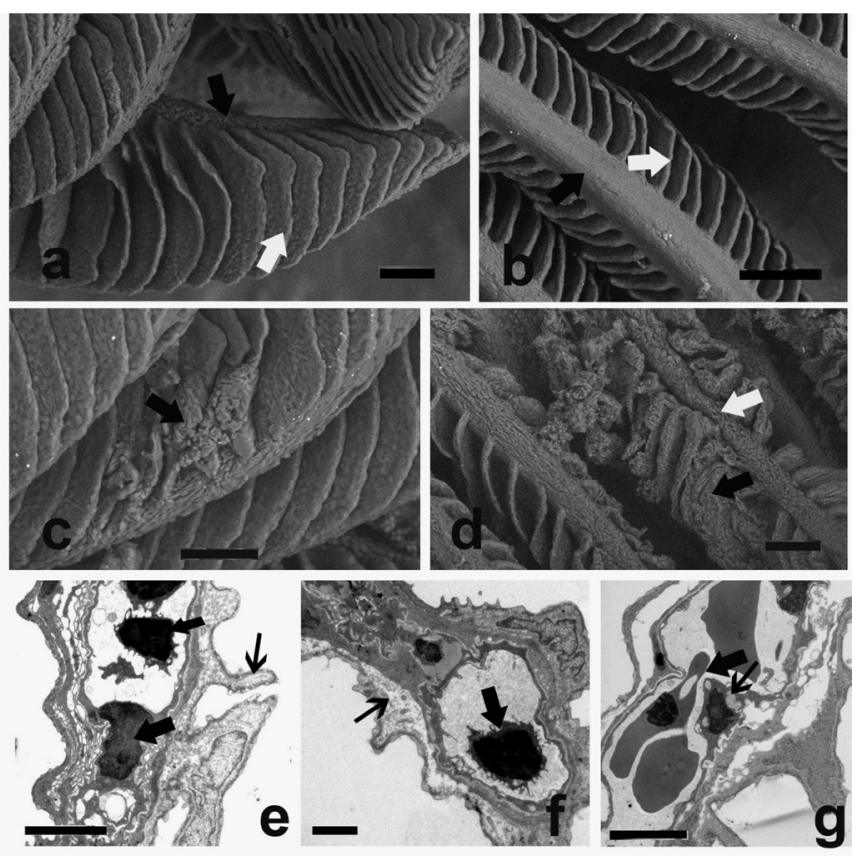

Figure 3. Gills external morphology (a, b, c and d) and ultrastructure (e, f and g) of Micropogonias furnieri. (a) and (b) normal aspect of the gills showing primary (black arrow) and secondary lamellae (white arrow); (c) hyperplasia of the secondary lamellae; (d) hyperplasia of the secondary lamellae (thin arrow) and alteration of the primary lamellae epithelium (white arrow); (e) top of the secondary lamellae with pilaster cell (arrow), capillary with leucocytes (smaller arrow) and epithelium projection (black arrow); (f) top of the secondary lamellae with capillary with leucocytes (arrow) and turgescent

epithelium (thin arrow); (g) pilaster cell alteration which is connecting neighbor capillaries (black arrow) and pilaster cell vacuolization (thin arrow). Bars (a): $20 \mu \mathrm{m}$; (b): $100 \mu \mathrm{m}$; (c): $20 \mu \mathrm{m}$; (d) $50 \mu \mathrm{m}$.

loss of the rounded nuclei shape in summer, while the steatosis, cytoskeleton disarrange changing the shape of rough endoplasmic reticule, and smooth endoplasmic reticule proliferation were more abundant in individuals from winter. 
Table 3. Occurrence of histopathological findings in Micropogonias furnier liver from studied sites in winter (2003) and summer (2004) seasons (means \pm standard deviation and two-way anova test). MMCs: melanomacrophage centers; MMs: melanomacrofages (ten individuals per site).

\begin{tabular}{lcccc}
\hline & \multicolumn{2}{c}{ Winter } & \multicolumn{2}{c}{ Summer } \\
\hline Lesions Type & reference & polluted & reference & polluted \\
\hline Necrosis & $\mathbf{0 . 0 8} \pm \mathbf{0 . 2 2}$ & $\mathbf{0 . 0 4} \pm \mathbf{0 . 0 7}$ & $0.58 \pm 0.49$ & $0.53 \pm 0.47$ \\
Leukocytes Infiltration & $0.08 \pm 0.13$ & $0.06 \pm 0.10$ & $0.28 \pm 0.32$ & $0.19 \pm 0.39$ \\
MMCs & $0.58 \pm 0.74$ & $0.01 \pm 0.02 *$ & $0.12 \pm 0.17$ & $0.05 \pm 0.07 *$ \\
MMs & $0.05 \pm 0.12$ & 0 & 0 & $0.20 \pm 0.06$ \\
Hemorrhage & $\mathbf{0 . 4 7} \pm \mathbf{0 . 3 8}$ & $\mathbf{0 . 3 0} \pm \mathbf{0 . 1 8}$ & $0.58 \pm 0.22$ & $0.70 \pm 0.36$ \\
\hline
\end{tabular}

Bold means differences between seasons and (*) Differences between sites

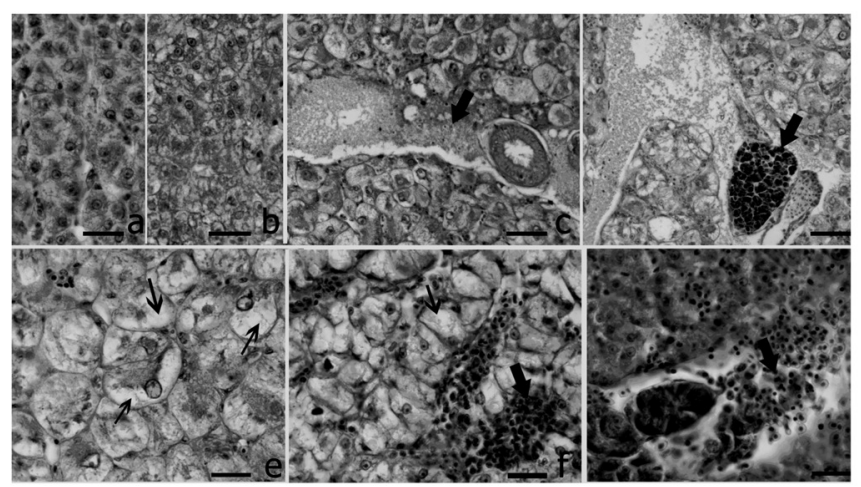

Figure 4. Liver histopathological analysis of Micropogonias furnieri. (a) Normal aspect of the hepatic parenchyma; (b) altered aspect of hepatic parenchyma; (c) necrosis (arrow); (d) melanomacrophage center - MMC

(arrow); hepatocyte steatosis in megalopathy cells; (f) megalopathy hepatocyte (thin arrow) and leucocytes infiltration (arrow); (g) necrosis and haemorrhage (arrow). Bars (a), (b), (e), (f) and (g): $5 \mu \mathrm{m}$; (c) and (d): $10 \mu \mathrm{m}$
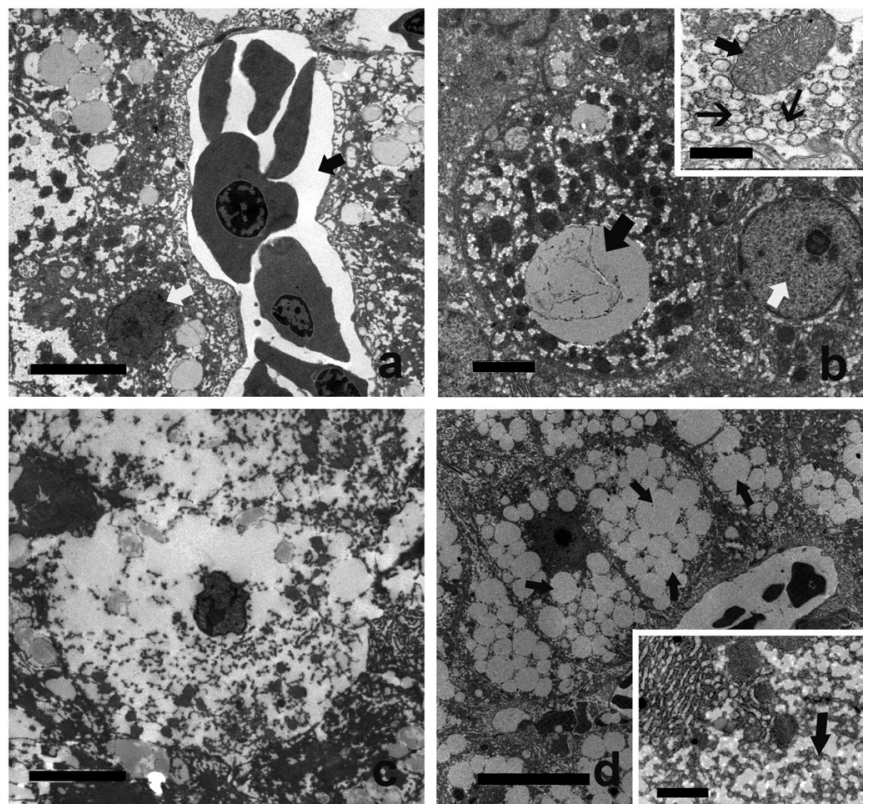

Figure 5. Liver ultrastructure of Micropogonias furnieri. (a) Hepatocyte nuclear alteration (white arrow), sinusoid containing red blood cells (black arrow); (b) atypical vesicles (black arrow) and normal nuclei (white arrow); (insert) Cytoskeleton alteration changing the rough endoplasmic reticule (thin arrow), observe a well preserved mitochondria (arrow); (c) necrosis area; (d) steatosis (arrow); (insert) smooth endoplasmic reticulum proliferation (arrow)

Bar: (a), (c) and (d): $5 \mu \mathrm{m}$; (b): $2 \mu \mathrm{m}$; (insert b): $1 \mu \mathrm{m}$; (insert d): $10 \mu \mathrm{m}$.

\section{DISCUSSION}

In Brazil more than $70 \%$ of urban regions are concentrated on coastal zone including estuaries. Controversially biomonitoring programs and impact of chemical released due human activities in these important regions are very scarce. Even the present results reveal a past condition (ten years ago), they are relevant to create a baseline to understand the impact of anthropogenic activities in the estuary currently. Except by the study of Amado et al. (2011), from our knowledge few additional information concern to the effects of human activities on fish species living in Lagoa dos Patos estuary has been published. Effectively, this study revealed the effects in $D$. rerio experimentally exposed to water from Lagoa dos Patos, but not as described here, in individuals chronically exposed. Thus, the current data are of substantial importance to show preterit results of the region that are essential to further studies, and increasing the knowledge in order to establish strategies or environmental rules for the estuary.

Particularly HSI reflects short-term nutritional status and metabolic energy demands (Pedlar et al., 2002). The increase of HSI as demonstrated in individuals from polluted site can be associated with lipids accumulation due to some pollutants exposure as discussed by Koehler (2004). The present results confirm the expected where specimens from the polluted site showed higher HSI then individuals from reference site without difference between individuals from distinct seasons. Thus, this parameter confirms and support the hypothesis that ten years ago the NPS was less affected by human activities.

The somatic as liver weight, total weight and total length are biometry data used to indicate health status in fish (Venancio \& Domingos, 2014). These values decreased in individuals collected in winter if compared with summer, meaning that winter is the period when the organisms are affected by stressors that can lead to physiological and biochemistry disturbs. The explanation could be the decrease of rain precipitation in this season altering the concentration of pollutants in water or sediment and consequently increasing its bioavailability (Forrester et al., 2003; Koehler, 2004; Ptashynski et al., 2001; Riba et al., 2005a; Zodrow et al., 2004). Additionally, TL and TW decreased in individuals from the most polluted site, corroborating that the worst water quality is related altering these parameters. Although the somatic index as TL, TW and LW are not conclusive in terms of water quality, they are very useful to indicate alterations at high levels of biological organization as physiology. These parameters associated with other as morphological will favor the understanding about the impact of chemicals in natural ecosystems. The increase of condition factor in individuals collected in winter independently of studied site are in opposite with other biometric indexes as TL, TW and LW, but could reflect the implications in adaptation of population inhabiting polluted environments (Venancio \& Domingos, 2014). According to Barbosa et al. (2012), the distribution of metals as lead, zinc, cupper and cadmium did not present variations along the port region, even in seasonal periods of 
the year. Although these data are more recent we can conclude that human activities are important source of pollutants to the studied species.

The high error observed in the current study reflect an acceptable individual variability in biomonitoring studies and have been obtained in other studies as well (Ferreira et al., 2004; Lease et al., 2003; Miranda et al., 2008; Oliveira Ribeiro et al., 2002; Rabitto et al., 2011). Particularly, can be explained by the mobility of this species in the estuary or even by different feeding strategies (Ferreira et al., 2004).

Corroborating the results discussed above, the lesions observed in gills of M. furnieri trough light and scanning electron microscopy are evidence that both sites are affected by chemical pollutants, but the most polluted area means to be more affected. This reinforce the needs of increase the use of different parameters in biommonitoring and lead to conclusion that the histopathological findings are highly representative and predictive as biomarker to evaluate the chemical exposure in field; giving a strong support to physiological explanations in terms of fish health.

Gills lesions reproduce both acute and chronic effects of exposure. The occurrence of hyperplasia and fusion of the secondary lamellae are physiologically at least the most severe damage to gills. According to Poleksic et al. (1994), the intensity of gill damage depends on the pollutant concentration and exposure time or even no lesion recovery. Liber et al. (2005) described that the recovery time in gills of fish is in general about 30 days, confirming the acute exposure to toxic chemicals in the current study. Additionally the observed severity of lesions in gills revealed the chronic exposure to pollutants in both studied sites, leading to potential physiological disturbs to the species. These findings were recently described by our group to other species of Brazilian tropical species naturally exposed to pollutants (Brito et al., 2012; Oliveira Ribeiro et al., 2005; Osório et al., 2014; Rabitto et al., 2011; Silva et al., 2012). According to the authors the histopathological findings investigated in tissues as gills are among the most efficient to evaluate the acute or chronic exposure and fish health.

According to Lease et al., (2003) the thin lamellar epithelium in gills is adapted for gas and ions exchange, and the alterations as described in the current study may affect the physiological role of gills corroborating the discussion above (Lease et al., 2003). The hyperplasia of secondary lamellae is an increase in cell number followed by lamellae fusion due to long-term exposure to chemicals (Bernet et al., 1999, Poleksic et al., 1994; Brito et al., 2012; Silva et al., 2012). This kind of lesion is the most important obstruction for gas diffusion and impairment for osmorregulation (Pacheco et al., 2002). According to Lease et al. (2003), the lamellae hyperplasia might be critical during hypoxia or metabolic stress determining the fish health. On this way, the current results showed that fishes from Lagoa dos Patos estuary are chronically exposed to chemicals suggesting physiological disturbs in both supposed reference and polluted areas.
Although parasites are commonly found in gills of fish as reported by Akaishi et al. (2004), the presence of parasites as observed could also represent disturbs in the immune system, responsible for an increased fish susceptibility. Rabitto et al. (2005) and Brito et al. (2012) defended the same interpretation. In fact, the parasite proliferation in gills of fish from polluted areas may be an indicative of low condition factor as observed in the current study that is more affected at summer. This result is in accordance with the decrease of melanomacrophage centers in liver of individuals from polluted site.

The damages and alterations found in liver corroborates the described above to gills. The leukocytes infiltration observed in liver means inflammatory responses in general due to lesions like necrotic cell death (Bernet et al., 1999). This finding is consistent with the present data where both infiltration and necrosis were found mainly in individuals collected at summer independent of the studied site, showed that the remobilization of pollutants typical in these season may be a cause of these effects. Necrosis represents a permanent damage in liver and is related with organ failure after long-term of exposure, and have been described as of high ecological importance (Bussolaro et al., 2012; Miranda et al., 2008; Osório et al., 2014; Rabitto et al., 2005). In addition, necrosis is a validated endpoint of effect due to multiple pollutants exposure of fish (Oliveira Ribeiro et al., 2002; Rabitto et al., 2011; Silva et al., 2012).

The occurrence of megalopathy cells or neoplasia represents a progressive change characterized by the enlargement of cell or tissue volume without increase of cell number (Bernet et al., 1999). This kind of alteration was found only in two individuals from reference site at winter. According to Stentiford et al. (2003), neoplasic lesions are related to long-term exposure and are more common in old fish, but also adversely in younger specimens when exposed to carcinogenic pollutants. The liver neoplasia identified in the present study as basophilic and acidophilic foci potentially represent an earlier stage of malignant lesions. This is an important category of histopathological findings, where chronic exposure to complex mixtures at low concentrations are the most frequent in aquatic environment impacted by human activities.

The occurrence of MMCs was higher only in specimens sampled from polluted site independent of seasons. MMCs are focal concentrations of pigmented macrophages (MMs) typically found in fish tissues presenting granular or heterogeneous pigmented materials inside the cells (Rabitto et al., 2005). Since MMCs are involved with several immune responses and metabolic functions, their presence may not necessarily represent pollutants exposure (Stentiford et al., 2003) but according to Rabitto et al. (2005) this finding can reflect increasing of phagocytic activity due to the occurrence of cell death. Controversially, there is some evidence that pollutants may also affect the leucocytes chemotaxy, inhibiting the role of MMCs (Fournier et al., 1998). Comparatively in polluted site the presence of lesions in liver and a smaller concentration of MMC were observed. This low incidence of 
MMC's from polluted area can be related with a decreasing in the immunological response as described by Koehler (2004), as necrosis are present in individuals from this site. Despite of that, the recent use of MMCs density as a biomarker and the difficulty to establish a method to confirm the role of pollutants on immune response in fish, this endpoint is recommended as a reliable biomarker of environmental contamination (Brito et al., 2012; Stentiford et al., 2003; Rabitto et al., 2011). Hemorrhagic events is described as a circulatory disturbance resulted from pathological condition of circulatory system. In the current study, as observed to necrosis this parameter was more frequent in individuals collected at summer confirming this season as a critical one for fish health in Lagoa dos Patos. The explanation, as discussed above, could be related with high temperatures that increases the individual metabolism, remobilization of pollutants due to the rain frequency increases and the high level of human occupation around the lake due to the vacation activities.

Some cytoplasmic disturbs such as steatosis mean regressive changes able to cause a functional reduction or even failure of the organ function. The storage of metabolic products, or lipids and glycogen can be affected by food availability, season, sex and reproductive cycle (Stentiford et al., 2003; Koehler, 2004). But also lipids are accumulated in liver due to harboring of lipophilic xenobiotics (Koehler, 2004) or even by disturbs in the lipid metabolism increasing the storage within cytoplasm. According to the same author, the increase of lipid droplets and cell death were the first effects in juvenile flounder exposed to toxic chemicals corroborating the steatosis as observed in the current study. This finding has been recommended as a biomarker of exposure to high lipophilic chemicals (Oliveira Ribeiro et al., 2005) as chlorine compounds and PAHs largely present in high impacted regions by human activities like estuaries. The increase of smooth endoplasmic reticule (SER) also detected in the present study, is another evidence of detoxification response due to organic pollutant exposure.

The present data lead to the needs of a multibiomarker approach in order to drive a more conclusive study to the region. Lagoa dos Patos receives important levels of domestic sewage in summer as an increasing of human activities around the lagoon is observed. The confirmation that the polluted area reflect in the worst health condition of fish and that the reference site can be also impacted by chemicals, are a very important data in terms of further studies to investigate the impact of human activities to the estuary of Lagoa dos Patos. The poverty of environmental studies in this important ecosystem highlight the current study and confirm the needs to establish if the conditions as described here still persist.

The lack of data concern to chemical and biological studies of pollutants present in Lagoa dos Patos, as discussed above, demonstrates the need of to stimulate further studies in the region. The current histopathological findings showed severe damages in gills and liver from individuals from both studied sites. These results per se is a motivation to increase the studies of human impact in the estuary. Additionally, the ecological and economical significance of the region, as described above, make urgent the integration with the chemical analysis and biological parameters to determine a more realistic health conditions of Lagoa dos Patos currently.

\section{ACKNOWLEDGEMENTS}

The authors want to thank the financial support from $\mathrm{CNPq}$ and Instituto do Milênio - RECOS; the technical support at Federal University of Rio Grande for animals collects and the technical assistance of Electron Microscopy Center at Federal University of Paraná.

\section{REFERENCES}

AKAISHI, F.M., SILVA DE ASSIS, H.C., JAKOBI, S.C.G., EIRAS-STOFELLA, D.R., ST-JEAN, S.D., COURTENAY, S.C., LIMA, E.F., WAGENER, A.L.R., SCOFIELD, A.L., OLIVEIRA RIBEIRO, C.A. 2004. Morphological and neurotoxicological findings in tropical fresh-water fish (Astyanax $s p$.) after waterborne and acute exposure to watersoluble fraction (wsf) of crude oil. Arch Environ. Contam. Toxicol., 46: 244 253. http://dx.doi.org/10.1007/s00244-003-2260-1

AMADO, L.L., ROSA, C.E., LEITE, A.M., MORAES, L., PIRES, W.V., LEÃES, G.L., MARTINS, C.M.G., ROBALDO, R.B., NERY, L.E.M., MONSERRAT, J.M., BIANCHINI, A., MARTINEZ, P.E., GERACITANO, L.A. 2006. Biomarkers in croakers Micropogonias furnieri (Teleostei:Sciaenidae) from polluted and non-polluted areas from the Patos Lagoon estuary (Southern Brazil): Evidences of genotoxic and immunological effects. Mar. Poll. Bull., 52: 199-206. http://dx.doi.org/ 10.1016/j.marpolbul.2005.11.006

AMADO, L.L., ROSA, C.E., CASTRO, M.R., VOTTO, A.P., COUGO SANTOS, L., MARINS, L.F.F., TRINDADE, G.S., FRAGA, D.S., DAMÉ, R.C.F., BARROS, D.M., GERACITANO, L.A., BIANCHINI, A., LA TORRE, F.R., MONSERRAT, J.M. 2011. Integrated biological responses of zebrafish (Danio rerio) to analyze water quality in regions under anthropogenic influence. Chemosphere, 82: 1563-1570. http:// 10.1016/j.chemosphere.2010.11.060.

BARBOSA, F.G., WALLNER-KERSANCH, M., BAUMGARTEN, M.G.Z. 2012. Metais traço nas áreas portuárias do estuário da Lagoa dos Patos, RS. Braz. J. Aqu. Sci. Techn.,16(2): 27-36. http://dx.doi.org/10.14210/bjast.v16n2.p27-36

BERNET, D.; SCHIMIDT, H.; MEIER, W.; BURKHARD-HOLM, P.; WAHLI, T., 1999. Histopathology in fish: proposal for a protocol to assess aquatic pollution. J. Fish Dis., 22: 25-34. http://dx.doi.org/0.1046/j.1365-2761.1999.00134.x

BRAGA, F.M.S. 1986. Estudo entre fator de condição e relação peso/ comprimento para alguns peixes marinhos. Rev. Bras. Biol., 46: 339-346.

BRITO, A.I., ARRUDA F., C., YAMAMOTO, F.Y., SILVA DE ASSIS, H.C., RODRIGUES SOUZA-BASTOS, L., CESTARI, M. M., CASTILHOS G., N., PRODOCIMO, V., FILIPAK NETO, F., OLIVEIRA RIBEIRO, C.A., 2012. Monitoring water quality in reservoirs for human supply through multi-biomarker evaluation in tropical fish. J. Environ. Monit., 14: 615-625. http:// dx.doi.org/ 10.1039/c2em10461j

BUSSOLARO, D., FILIPAK NETO, F., GLINSKI , R., H., MELA, M., SILVA DE ASSIS, H.C., OLIVEIRA RIBEIRO, C.A., 2012. Bioaccumulation and related effects 
of PCBs and organochlorinated pesticides in freshwater fish Hypostomus commersoni. J. Environ. Monit., 14: 2154-2163. http://dx.doi.org/ 10.1039/c2em10863a

COOLEY, H. M., FISK, A. T., WIENS, S. C., TOMY, G. T., EVANS, R. E., MUIR, D. C. G., 2001. Examination of the behavior and liver and thyroid histology of juvenile raibow trout (Oncorhynchus mykiss) exposed to high dietary concentrations of $\mathrm{C}_{10^{-}}, \mathrm{C}_{11^{-}}, \mathrm{C}_{12^{-}}$and $\mathrm{C}_{14^{-}}$polychlorinated $n$-alkanes. Aqua Toxicol, 54: 81-99. http://dx.doi.org/ 0166-445X/01/s

FERREIRA, M.; ANTUNES, P., GIL, O., VALE, C., REISHENRIQUES, M. A., 2004. Organochlorine contaminants in flounder (Platichthys flesus) and mullet (Mugil cephalus) from Douro estuary, and their use as sentinel species for environmental monitoring. Aquat Toxicol, 69: 347-357. http://dx.doi.org/ 10.1016/j.aquatox.2004.06.005

FORRESTER, G.E., FREDERICKS, B.I., GERDEMAN, D., EVANS, B., STEELE, M. A., ZAYED, K., SCHWEITZER, L. E., SUFFET, I. H., VANCE, R. R., AMBROSE, R. F. 2003. Growth of estuarine fish associated with the combined concentration of sediment contaminants and shows no adaptation or acclimation to past conditions. Mar Environ Res, 56: 423-442. http://dx.doi. org/ 10.1016/S0141-1136(03)00004-7

FOURNIER, M., LACROIX, A., VOCCIA, I., BROUSSEAU, P. 1998. Phagocytic and metabolic activities of macrophages from mummichog naturally exposed to pulp mill effluents in the Miramichi River. Ecotoxicol Environ Saf, 40: 177-183.

GARCIA, A. M., VIEIRA, J. P. 2001. O aumento da diversidade de peixes no estuário da Lagoa dos Patos durante o episódio EL NIÑO 1997-1998. Atlântica, Rio Grande, 23: 85-96.

GUSSO-CHOUERI, P. K., CHOUERI, R. B., SANTOS, G. S., ARAUJO, G. S.,

CRUZ, A. C. F., STREMEL, T., CAMPOS, S. X., CESTARI, M. M., OLIVEIRA

RIBEIRO, C. A., ABESSA, D. M. S. 2016. Assessing genotoxic effects in fish from a

marine protected area influenced by former mining activities and other stressors.

Mar Poll Bull, 104: 229-239. http://dx.doi.org/10.1016/j. marpolbul.2016.01.025

HAIMOVICI, M., VASCONCELLOS, M., KALIKOSKI, D.C., ABDALAH, P., CASTELLO, J.P., HELLEBRANT, D. 2006. Diagnóstico da pesca no Rio Grande do Sul. In: Isaac, V., MARTINS, S.A., HAIMOVICI, M., ANDRIGUETTO, J.M. (Eds.), A Pesca Marinha e Estuarina do Brasil no Início do Século XXI: recursos, tecnologias, aspectos socioeconômicos e institucionais. Publicação do Especial do Projeto: Uso e Apropriação de Recursos Costeiros-Modelo Gerencial da Pesca. Instituto do Milenio/CNPq Editora Universitaria UFPA, Belem, Brazil, pp. 157-180.

HILE, R. 1936. Age and growth of the cisco Leucichthys artedi (Le Sueur), in the lakes of the north-eastern highlands, Wisconsin. Bull. U.S. Bureau Fish. 48: 211-317

KEHRIG, H. A., MALM, O., MOREIRA, I. 1998. Mercury in a widely consumed fish Micropogonias furnieri (Desmarest, 1823) from four main Brazilian estuaries. The Sci Total Environ, 213: 263-271. http://dx.doi.org/ 10.1016/S00489697(98)00099-0

KOEHLER, A. 2004. The gender-specific risk to liver toxicity and cancer of flounder (Platichthys flesus (L.)) at the German Wadden Sea coast. Aqu Toxicol, 70: 257-276. http://dx.doi. org/978012388254-4

LEASE, H.M., HANSEN, J.A., BERGMAN, H.L., MEYER, J.S. 2003. Structural changes in gills of Lost River suckers exposed to elevated $\mathrm{pH}$ and ammonia concentrations. Comp Biochem
Phisiol, Part C, 134: 491-500. http://dx.doi.org/ 10.1016/ S1532-0456(03)00044-9

LIBER, K., WEBER, L., LÉVESQUE, C. 2005. Sublethal toxicity of two wastewater treatment polymers to lake trout fry (Salvelinus namaycush). Chemosphere, 61:1123-1133. http://dx.doi. org/10.1016/j.chemosphere.2005.03.004

LUZ, L.P., SANCHES FILHO, P.J., SOUSA, E.E.H., KERSTNER, T., CARAMÃO, E.B. 2010. Evaluation of surface sediment contamination by polycyclic aromatic hydrocarbons in colony Z3 - (Patos Lagoon, Brazil). Microchem J, 96 (1): 161-166. http://dx.doi.org/ 10.1016/j.microc.2010.03.003

MARCOVECCHIO, J. E. 2004. The use of Micropogonias furnieri and Mugil liza as bioindicators of heavy metals pollution in La Plata river estuary, Argentina. Sci Total Environ, 323: 219-226. http://dx.doi.org/10.1016/j.scitotenv.2003.09.029

MARTIN, W.R. 1949. The mechanics of environmental control of body form in fishes. University Toronto, (Publ. Ont. Fish. Res. Lab. 70), Stud Biol. 58: 1-91.

MARTINS, I.M., DIAS J.M., FERNANDES, E.H., MUELBERT, J.H. 2007. Numerical modelling of fish eggs dispersion at the Patos Lagoon estuary, Brazil. J Mar Syst, 68: 537-555. http:// dx.doi.org/10.1016/j.jmarsys.2007.02.004

MEDEIROS, P.M., BÍCEGO, M.C., CASTELÃO, R.M., DEL ROSSO, C., FILLMANN, G., ZAMBONI, A.J. 2005. Natural and anthropogenic hydrocarbon inputs to sediments of Patos Lagoon Estuary, Brazil. Environ Int, 31 (1): 77-87. http://dx.doi. org/ 10.1016/j.envint.2004.07.001

MILTON, D. A., BLABER, S. J. M., RAWLINSON, N. J. F. 1994. Reproductive biology and egg production of three species of Clupeidae from Kiribati, tropical central Pacific. Fish Bull, 92: 102-121.

MIRANDA, A.L., ROCHE, H., RANDI, M.A.F., MENEZES, M.L., OLIVEIRA RIBEIRO, C.A. 2008. Bioaccumulation of chlorinated pesticides and PCBs in the tropical freshwater fish Hoplias malabaricus: Histopathological, physiological, and immunological findings. Environ Int, 34: 939-949. http://dx.doi. org/10.1016/j.envint.2008.02.004

MIRANDA, R. G., GRÖTZNER, S. R., VOIGT, C. L., CAMPOS, S. X., RANDI, M. A. F., OLIVEIRA RIBEIRO, C. A., FILIPAK NETO, F. 2016. Effects of realistic concentrations of $\mathrm{TiO} 2$ and $\mathrm{ZnO}$ nanoparticles in Prochilodus lineatus juvenile fish. Environ Sci Poll Res Int, 23: 5179-5188.

NIENCHESKI, L.F., WINDOM H.L., BARAJ B., WELLS D., SMITH.R. 2001. Mercury in fish from Patos and Mirim Lagoons, Southern Brazil. Mar Poll Bull, 42(12):1403-1406. http://dx.doi. org/ 10.1007/s10661-008-0610-1

OLIVEIRA RIBEIRO, C. A., BELGER, L., PELlETIER, É., ROULEAU, C. 2002. Histopathological evidence of inorganic mercury and methyl mercury toxicity in the artic charr (Savelinus alpinus). Environ Res, 90: 217-225. http://dx.doi.org/ 10.1016/ S0013-9351(02)00025-7

OLIVEIRA RIBEIRO, C. A., VOLLAIRE, Y., SANCHEZCHARDI, A., ROCHE, H. 2005. Bioaccumulation and the effects of organochlorine pesticides, PAH and heavy metals in the Eel (Anguilla anguilla) at the Camargue Nature Reserve, France. Aqu Toxicol, 74: 53-69. http://dx.doi.org/ 10.1016/j. aquatox.2005.04.008

OSORIO, F.H.T., OLIVEIRA, L.F.S., PIANCINI, L.D.S., AZEVEDO, A.C.B., LIEBEL, S., YAMAMOTO, F.Y., CHIMENTÃO, F.G., PHILIPPI, V.P., OLIVEIRA, M.L.S., BOIT, K., ORTOLANI-MACHADO, C.F., FILIPAK NETO, F., CESTARI, M.M., SILVA DE ASSIS, H.C., OLIVEIRA RIBEIRO, C.A. 2014. Water quality assessment of the Tubarão River through chemical analysis and biomarkers in 
the Neotropical fish Geophagus brasiliensis. Environ Sci Poll Res Int, 21: 9145-9160. http://dx.doi.org/ 10.1007/s11356-013$1512-5$

PACHECO, M., SANTOS, M. A. 2002. Biotransformation, genotoxic, and histopathological effects of environmental contaminants in European eel (Anguilla anguilla L.). Ecotoxicol Environ Safety, 53: 331-347. PII: S0147-6513(02)00017-9

PEARCY, W.G., MYERS, S.S. 1974. Larval fishes of Yaquina Bay, Oregon: a nursery ground for marine fishes? Fisheries Bulletin of United States, 72: 201-213.

PEDLAR, R.M., PTASHYNSKI, M.D., EVANS, R., KLAVERKAMP, J.F. 2002. Toxicological effects of dietary arsenic exposure in lake whitefish (Coregonus clupeaformis). Aqu Toxicol, 57 : 167-189. PII: S0166 - 445X(01)00198 - 9

POLEKSIC, V., MITROVIC-TUTUNDZIC, V. Fish gills as a monitor of sublethal and chronic effects of pollution. In: Müeller, P.R., Lloyd, R., 1994. Sublethal and chronic effects of pollutants on freshwater fish. Oxford. Fish News books, 30: 339-352.

PTASHYNSKI, M.D., PEDLAR, R.M., EVANS, R., WAUTIER, K.G., BARON, C.L., KLAVERKAMP, J.F. 2001. Accumulation, distribution and toxicology of dietary nickel in lake whitefish (Coregonus clupeaformis) and lake trout (Salvelinus namaycush). Comp Biochem Phisiol Part C, 130: 145-162. http://dx.doi.org/ 10.1016/j.aquatox.2012.03.016

RABITTO, I.S., ALVES COSTA, J.R.M., SILVA DE ASSIS, H.C.; PELLETIER, É., AKAISHI, F.M.; ANJOS, A., RANDI, M.A.F.; OLIVEIRA RIBEIRO, C. A. 2005. Effects of dietary $\mathrm{Pb}$ (II) and tributyltin on neotropical fish, Hoplias Malabaricus: histopathological and biochemical findings. Ecotox Environ Safety, 60: 147-156. http://dx.doi.org/10.1016/j. ecoenv.2004.03.002

RABITTO, I.S., BASTOS, W.R., RONALDO ALMEIDA, R., ADILSON ANJOS, A., HOLANDA, I.B.B, GALVÃO, R.C.F., FILIPAK NETO, F., MENEZES, M.L., SANTOS, C. A. M., OLIVEIRA RIBEIRO, C. A. 2011. Mercury and DDT exposure risk to fish-eating human populations in Amazon. Environ Int, 37: 56-65. http://dx.doi.org/10.1016/j.envint.2010.07.001
RIBA, I.; BLASCO, J., JIMÉNEZ-TENORIO, N., ÁNGEL DELVALLS, T. 2005. Heavy metal bioavailability and effects: I. Bioaccumulation caused by mining activities in Gulf of Cádiz (SW, Spain). Chemosphere, 58: 659-669. http://dx.doi. org/0.1016/j.chemosphere.2004.02.015

SANCHES FILHO, P. J., LUZ, L. P., BETEMPS, G. R., CARAMÃO, E. B. 2012. Evaluation of surface sediment contamination by polycyclic aromatic hydrocarbons in the "Saco do Laranjal", - (Patos Lagoon, Brazil). Mar Poll Bull, 64: 1933-1937. http:// dx.doi.org/ 10.1016/j.marpolbul.2012.04.010

SILVA, G.S., FILIPAK NETO, F., SILVA DE ASSIS, H.C., BASTOS, W.R., OLIVEIRA RIBEIRO, C.A. 2012. Potential risks of natural mercury levels to wild predator fish in an Amazon reservoir. Environ Monit Assesmen, 184: 4815-4827. http://dx.doi.org/ 10.1007/s10661-011-2304-3

STENTIFORD, G. D.; LONGSHAW, M.; LYONS, B. P.; JONES, G.; GREEN M.; FEIST S. W. 2003. Histopathological biomarkers in estuarine fish species for the assessment of biological effects of contaminants. Mar Environ Res, 55: 137-159. http://dx.doi. org/ 10.1016/j.marenvres.2015.02.004

VICENTINI, R.V., ARAUJO, F.G. 2002. Caracterização morfométrica da corvlnaMicropogonias furnieri (Desmarest) (Pisces, Sciaenidae) na Baía de Sepetiba, Rio de Janeiro, Brasil Rev Bras Zool, 19 (1): 63-170, http://dx.doi.org/ 10.1590/S010181752002000500010

VENANCIO, L.P.R. AND DOMINGOS, C.R.B. Effect of Pollutants on Condition Index. Pollution and Fish Health in Tropical Ecosystems. Eds. Almeida E A and Oliveira Ribeiro CA, CRC Press, Boca Raton, USA, 1914, p.338-349.

ZODROW, J.M., STEGEMAN, J.J., RANGUAY, R.L. 2004. Histological analysis of acute toxicity of 2,3,7,8-tetrachlorodibenzo- $p$-dioxin (TCDD) in zebrafish. Aquat Toxicol, 66: 25-38. http://dx.doi.org/ 10.1016/j. aquatox.2003.07.002 